ECONOMICS

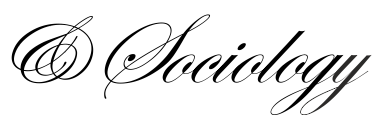

\title{
MARKET COMMUNICATION: ETHICAL AND PRAXEOLOGICAL DIMENSIONS
}

\author{
Olgierd Swiatkiewicz, \\ Polytechnic Institute of Setúbal, \\ Setúbal, Portugal, \\ E-mail: \\ olgierd.swiatkiewic?@estsetubal.ips.pt
}

Received: January, 2018

1st Revision: March, 2018

Accepted: April, 2018

DOI: $10.14254 / 2071-$

789X.2018/11-2/13

\begin{abstract}
Communication is one of the main organizational processes and at the same time one of the four basic marketing variables. Apart from some specific aspects of interpersonal communication, in this paper, we focus on the key issues of communication with the market and its stakeholders, because it determines the sales of products and services in a competitive environment, and consequently affects the income and profit of the company. The main aspect of communication with the market is its effectiveness (including the issues of ineffectiveness and/or countereffective action) and the relationship of expenditures and revenues (efficiency, etc.), i.e. the praxeological dimension. From the beginning of marketing, the ethical aspect of communication has also arisen some doubts which are still on the table. In recent times, the area was dominated by the issue of corporate social responsibility (CSR). In this article, we address numerous issues of communication with the market, but it is far from being exhaustive. The basic method adopted here is a review of the literature in this field.
\end{abstract}

Keywords: communication; praxeology; ethics; marketing; advertising; public relations; social marketing; philanthropy; product placement; corporate social responsibility.

\section{Introduction}

Communication is a dynamic and continuous process, which is shaped by knowledge, opinions and attitudes of interacting entities, representing certain values and interests (Kuraszko, 2012). Communication is one of the basic functions and one of the key organizational processes (Mitchell, 1982). "In corporate communication /.../ the relationship between an organization and its stakeholders $/ \ldots /$ is viewed as defining the discipline" (Frandsen \& Johansen, 2015, p. 253). Organizational communication has many distinct aspects, forms and goals (Karnaukhova \& Polyanskaya, 2016). It is often not ethically neutral because it can serve indoctrination, manipulation, etc. In this paper, we intend to focus on a broad issue of market communication, namely communication at organization level (institutional communication) and at the marketing level. In every company, there is, in fact, one major feature to be met - selling products and services as a function of revenue generation (Freire, 1998; Gautier \& Pache, 2015). For this reason, the formulation of a company's strategy begins with a product and market/industry strategy (Freire, 1998), and this is largely a marketing field. 
However, in marketing, the meaning of the market in a wide sense, refers not only to all groups/publics (enterprises, institutions) but also to individuals and distinct factors that may influence the sales of products or services, or, more broadly, the organization's activity, such as target customers/clients, consumers/users/patients/voters, advisers/recommenders or prescribers, competitors, distributors/intermediaries (Lindon et al., 1992/2010). Without much effort, one can see that this concept overlaps mostly the notion of stakeholders, it means, all those people, groups or organizations that may have an impact on the organization or on which it can exercise an impact, as well as those whose welfare depends on the organization, i.e. owners (shareholders, investors, etc.), employees, customers, suppliers, competitors, distributors/dealers, financial institutions, interest groups, local communities, courts, municipalities, local authorities, educational institutions, natural environment, etc. (Buchholz \& Rosenthal, 1998; Freeman, 2002; European Commission, 2001).

We assume according to Lindon et al. (1992/2010) that communication is a set of signals emitted by the company towards its recipients (customers, intermediaries, opinion leaders and all targets), and therefore it is a social process of exchange of information and ideas through language and other signs (Karnaukhova \& Polyanskaya, 2016).

The primary purpose of this paper is trying to answer the question of how to communicate efficiently with the market (effectively and economically) and at the same time to increase the common good, or at least do not moral and/or economic harm to stakeholders. Therefore, the criteria of analysis are the praxeological (e.g. Gasparski, 1993; Dudley, 1995) and ethical dimensions of communication with the market.

The novelty of the paper consists in a simultaneous - praxeological and ethical analysis of the selected instruments/tools or measures of market communication of the companies. As the object of analysis, we have selected some older (advertising, public relation and organizational philanthropy) and some fresher (social marketing, product placement and corporate social responsibility) instruments/tools or measures of communication with the market used by companies.

The main method used in this study to achieve the objective is the review and analysis of the literature in the field of management, marketing, business ethics and related disciplines. For this purpose, we have searched largest international data bases of academic journals with the assistance of Biblioteca do Conhecimento Online, known in Portuguese academic/scientific circle as $b$-on (www.b-on.pt).

Therefore, the next two sections are dedicated to two criteria for analyzing the communication tools with the market, i.e. praxeological (the classical approach) and ethical ones. In the other sections, we discuss selected instruments of company's communication with the market, starting discussions on advertising and public relations, product placement, organizational philanthropy, cause-related marketing and, ending up with communicating corporate social responsibility.

As this is a review paper, it has a different structure, it takes the form of an essay, and the methodology is less salient because it summarizes the existing literature and explains current knowledge about the topics.

\section{The classical approach to market communication: communication as a marketing variable}

To communicate effectively with the market, companies form their salespeople, hire advertising agencies, promotional and direct marketing specialists, and public relations experts (Kotler, 1967/94; Kotler et al., 1996; Kuraszko, 2012).

Effective communication is often portrayed as the cause of the greatest successes of a company, while ineffective communication serves many times as an explanation of their 
failures. (Mitchell, 1982). Effective communication increases the company's performance (Lai, 2016). The communication process consists of many elements, which list, more or less numerous, depending on the interpretation and the approach of each author. In this process, the most common are sender/source of communication, message, encoding, channel, receiver, decoding, noise and response/feedback (Mitchell, 1982; Kotler, 1967/94; Lindon et al., 1992/2010). Typically, components of the communication model are presented sequentially even though it is a dynamic, multilevel, complex process (Karnaukhova \& Polyanskaya, 2016), in which sender and receiver do not always interpret likewise the meaning of the same message. At any point in this process, loss or reduction of the effectiveness of communication, and various moral problems may arise.

In marketing, market communication is one of the four basic decision variables of a socalled marketing mix, including price, product/service, and distribution. (Kotler, 1967/94; Kotler et al., 1996; Lindon et al., 1992/2010). The communication variable also has its own composition, which consists mainly of such basic elements as advertising, sales promotion, direct/personal selling and public relations (Kotler, 1967/94; Kotler et al., 1996; Lindon et al., 1992/2010). Each of these elements of communication with the market has numerous specific tools/instruments. Other elements of marketing composition also communicate (design, color, brand, product packaging, price, discounts, preferred distribution channels, etc.), and the organization itself, through its architecture, employee attitude, clothing and language, and the way they treat the stakeholders, themselves, their subordinates or superiors.

In recent years, companies are increasingly using new communication techniques and new media such as corporate websites, blogs, social networks, discussion groups, short message service (SMS), which creates new opportunities and new threats. At the same time, thanks to these technological advancements, the traditional boundaries between advertising and public relations practices, for example, are no longer so explicit (Schauster \& Neill, 2017).

\section{The ethical dimension of communication with the market}

Just as every human action (including inaction, as well as omission of action) and its effects may be subject to moral/ethical analysis and judgment (Ossowska, 1970/85; Grzegorczyk, 1989), so can each communication component be analyzed and evaluated from the point of view of a moral/ethical criterion. However, as evidenced by the trends visible in practice and in the literature of the subject, some issues or aspects of communication raise a more ethical concern or interest than others, hence more research and publications about it. The "hot topics" of company communication with the market, beyond the classical topics as advertising and public relations, include product placement. In addition, cause-related marketing, philanthropy and corporate social responsibility also arouse a great deal of emotion and doubt. On the one hand, companies are pressured to assume social and environmental responsibilities, on the other hand, as they assume the costs of it, they want to use these initiatives to differentiate themselves from the competition in the industry and they want the market (stakeholders) to know about it (what they do and what it is for), then companies have to report it (Jahdi \& Acikdilli, 2009). The latter issue also involves the fundamental problem of the credibility of the source itself, as consumers are suspicious of corporate social responsibility initiatives undertaken by companies (Jahdi \& Acikdilli, 2009; Lock et al., 2016). Marketing managers themselves, through their unethical behavior, may also influence the negative image of this activity (Garbarski, 2012), just as the attitude and behavior of salespeople directly affect consumers' perceptions of products, brands and companies (Lai, 2016). In addition, the unethical behavior of the company's top management can have a strong negative impact on other employees (Drumwright \& Murphy, 2009). 
As Porter and Kramer (2002), for example, point out, what is commonly referred to as strategic philanthropy is neither philanthropic, in the strict sense, nor strategic for the company, because philanthropy is used in public relations and advertising to promote a company/brand image and to improve its reputation, through social marketing or other sponsored activity. Moreover, it is still used to raise employees' morale, increase company/brand visibility, and thus gain customers' loyalty, the goodwill of the local community or employees' commitment (Porter \& Kramer, 2002; Brammer et al., 2006). There are often serious doubts about what the purpose of such behavior is and whether it does not trigger social cynicism about the motives of the company (Porter \& Kramer, 2002). The issue is similarly treated by Jahdi and Acikdilli (2009) and Lock et al. (2016), who refer the difficulties encountered by the company intending to communicate its social responsibility. As mentioned by the authors, the proliferation of the so-called "greenwashing", and other dysfunctional forms of communication (e.g. astroturfing or astroturf lobbying, flogging versus blogging, etc.) or unjustified ethical declarations contribute to the loss of confidence, cynicism and criticism, as well as consumers suspicion (Jahdi \& Acikdilli, 2009; Delmas \& Burbano, 2011; Lock et al., 2016); while increasing information on consumer's behavior, thanks to data mining and other technological tools, raises other ethical concerns (Schauster \& Neill, 2017).

\section{Advertising and public relations}

Advertising is one of the more effective tools of communicating with the market (Hazaparu, 2014). Its merits include the promotion of competition between companies/brands, provision of necessary information to consumers/users, enabling consumers to make smart choices between the offered products/services, and stimulating innovation and the development of new products/services (Hazaparu, 2014). According to research, advertising usually has a significant impact on the immediate and deferred growth of recall of a brand/product (Uribe \& Fuentes-García, 2015).

Advertising is everywhere and as one of the most well-known and ubiquitous tools of the market communication is still blamed for many evils (Jahdi \& Acikdilli, 2009; Drumwright \& Murphy, 2009; Hazaparu, 2014).

According to some authors (Jahdi \& Acikdilli, 2009; Hazaparu, 2014), the key criticism of advertising is the conviction that cutting associated costs would reduce the financial expenses borne by purchasers of products/services because advertising costs increase the purchase price of the product on the market. In addition, other allegations are made about advertising that is intrusive and one cannot get rid of, that litters the environment, creates false expectations, encourages consumers to make emotional and irrational decisions, and that is characterized by contradiction between the subjective way of product advertisement and what the product actually is (Drumwright \& Murphy, 2009; Jahdi and Acikdilli, 2009; Hazaparu, 2014). According to Edelman (2006), mentioning the marketing executives of large international companies, the peak of the effectiveness of mass marketing communication, when advertising is top, belongs to the past.

As Shimp (1997, apud Jahdi \& Acikdilli, 2009) refers, the negative social effects of advertising include the fact that it is sometimes false, misleading, deceptive, manipulative, offensive and in bad taste. Other negative social effects are creating and perpetuating stereotypes, encouraging the purchase of unnecessary objects, and playing on the uncertainty and fear of people. In turn, Pollay and Gallagher (1990, apud Jahdi \& Acikdilli, 2009) point to the side effects of advertising, because when advertising refers to certain symbols, it also promotes unwanted phenomena or behaviors, namely: targeting the mass consumer promotes conformism; a reference to sexuality can be an incentive to pornography; rising fear may awaken chronic anxiety; recourse to a socially occupied position can cause envy and social 
competition; showing youth can promote disdain in older people, and referring to novelty can affect disrespect for tradition. Hazaparu (2014) adds that advertising serves private interests instead of what is commonly considered the social interest.

According to research, most of the advertising uses a low level of involvement in the processing of information, what is neither subconscious nor unconscious, but a process with a slight cognitive engagement (Heat, 2001, apud Eagle \& Dahl, 2015). Smarandescu and Shimp (2015) have shown that it is unlikely that subliminal prime advertising influenced consumer choice under realistic market conditions.

Despite significant changes in recent years or decades, many of the traditional ethical issues related to advertising are the same (Drumwright \& Murphy, 2009). However, it is important to distinguish issues related to advertising from issues related to the activities of advertising agencies: when it comes to advertising, the leaders of leading advertising companies consider that ethical issues are different in their nature compared to traditional problems, because of the electronic media (Internet, blogosphere, etc.); in the case of ethical issues concerning the activities of advertising companies, there are no differences in their nature compared to traditional problems, while differences in scale are observed, making the risks, rewards and temptations bigger nowadays (Drumwright \& Murphy, 2009).

As Finn (1959) states, one of the main public relations functions should be to explain the role that a company plays in society and to create mutual understanding, i.e. building bridges between industry and society. Public relations serve to maintain good relationships between companies and the market/stakeholders (Lindon et al., 1992/2010) and to gain social support (Finn, 1959), but also to build a positive brand reputation and brand awareness among consumers, as well as to achieve success in the market (Edelman, 2006). On the other hand, public relations are accused of littering the media, manipulating public opinion, distorting reality, not telling the whole truth, or creating an artificial image of a company/brand/product, ending each message with a positive return, inventing a story or writing a story anew (Finn, 1959; Hallahan, 1994). "In public relations, truth is a hard word" (Finn, 1959, p. 56). Public relations, like advertising, now have access to a variety of communication channels. All these technological means (Internet - portals/corporate websites, blogging, social media, TV satellite channels, telemarketing, multimedia, cable TV, e-mail, mobile phones, newsletters, e-news and reports) enable companies to have more direct and effective access to customers than it was possible when the market was dominated by newspaper, radio and television (Hallahan, 1994; Edelman, 2006). According to Hallahan (1994), not all of these alternatives available through modern technology are equally effective and/or serving the public interest, as they can lead, inter alia, to the sense of isolation and confusion among consumers caused by information hoarding (information overloading), or the rejection of any content delivered as noise (communication distortions); in addition, most often they lack credibility, which was enjoyed by the news appearing in the public press. According to Edelman (2006), however, more and more Internet users are no longer passive consumers and become active creators of information, sharing their ideas and views, questioning suggested by other worldviews, composing their own messages, trusting each other more than traditional authority, or the press. In these new communication means one can often find some forms of impersonation, pretending independence, fictional initiatives/grassroots movements, falsification of identity, with the aim of legitimizing the company's activity, such as astroturfing or astroturf lobbying, flogging, etc. (Cádima, 2016; Lock et al., 2016).

\section{Product/brand placement}

Product/brand placement is paid, it is intentional, subtle and creative placement of a brand or other distinctive identifiers/elements (signs, symbols, etc.), through audiovisual 
means, quotes or references, in the content of TV/radio programs, games, magazines or mass events, instead of or as a supplement to advertising (Kowalczyk \& Royne, 2012; Uribe \& Fuentes-García, 2015; Davtyan \& Cunningham, 2017). Product placement, as well as advertising, is intended to influence the cognitive, emotional, and behavioral responses of consumers. (Uribe \& Fuentes-García, 2015). Unlike advertising, according to Eagl and Dahl (2015), low levels of consumer engagement and unconscious processing of information for product placements should be explored in depth.

When the advertising of certain products is legally prohibited or restricted, it is replaced by product placement, which, as a tool of market communication, serves the same purposes as advertising, e.g. influencing the cognitive (branding, brand recall), emotional (building positive attitudes towards the brand/product), and behavioral (inclination or disposition to purchase or consumption of the product, increase in orders) reactions of customers (Uribe \& FuentesGarcía, 2015).

Product placement is an effective tactic targeted at sensitive audiences (Davtyan \& Cunningham, 2017). It is a form of brand/product communication without the possibility of being rejected by the viewer/listener/receiver and therefore attractive to the company (Eagle \& Dahl, 2015; Uribe \& Fuentes-García, 2015). Product placement can take many forms, but its goal is to place a recognizable branded product in the content or background of various media (Eagle \& Dahl, 2015). Product placement not only occurs in traditional media (television, radio, film, etc.), but it is also a common form in computer games (e.g. computer game consoles or advergames $=$ advertise + video game), in mobile applications, in music videos/video clips, in social media (Facebook, Twitter, YouTube, etc.), etc. (Eagle \& Dahl, 2015).

A study by Davtyan and Cunningham (2017) shows that consumers have a more positive attitude towards brand placement than to television advertising; product placement seems to be a more effective form of communication than a television advertising spot, especially if the message is targeted to the audience with low ad tolerance. Furthermore, the combination of advertising and product placement in one program does not significantly affect the attitude of the audience to the brand or the intention to increase the purchase of products (Davtyan \& Cunningham, 2017).

In the literature, a widely-discussed issue is the significant impact of product placement on particularly vulnerable/sensitive groups, such as children and adolescents, because they are immature in terms of cognitive development, they have not developed consumer skills yet, and therefore they have limited ability to understand and defend against persuasive communication (Eagle \& Dahl, 2015; Uribe \& Fuentes-García, 2015). Studies on the impact of product placement are frequent and often deal with its risks to health, life or development of young people, such as alcohol, tobacco and junk food, and the tendency to buy and consume them. Moreover, it may lead to the development of diseases, unwanted addictions, crime, obesity and related social problems and costs.

Uribe and Fuentes-García (2015), investigating the influence of the placement of unhealthy foods on different age groups of children and youth (9, 12 and 15 years), found out the existence of an increased brand awareness and increased behavioral disposition in the experimental group compared to control group. The authors also received an increase in the impact of this type of communication directed towards children and adolescents, with the combined (synergetic) use of advertising with product placement.

Another significant problem with product placement is the lack of clear legal regulations, or other forms of control for products with a potential negative impact on consumers' behavior (e. g. alcohol, tobacco products, ENDS - electronic nicotine delivery systems), while attempting to use this mean of communication by companies producing goods covered by the prohibition of advertising (Eagle \& Dahl, 2015). 
As it is evident from the literature, product placement impact research focuses on brand awareness rather than the consumers' behavior that leads to its purchase, consumption or use (Eagle \& Dahl, 2015). The results of the research on perceptions of product placement by children and adolescents are clearly contradictory and the acceptability of placement generally varies depending on the product concerned and how it is included in the broader message, although not every product placement seems to be effective (Eagle \& Dahl, 2015). In addition, Eagle and Dahl (2015) point out the lack of a clear ethical dimension in theories and concepts of product placement.

\section{Philanthropy and cause-related marketing}

Organizational philanthropy, according to Gautier and Pache (2015), is a voluntary financial donation from a company for charity, made directly in the form of a grant or through a foundation created by the company. The earlier mentioned authors in the definition of philanthropy omit donations in-kind, limiting it only to financial donations, but in the literature of the subject, if philanthropy is defined at all, it is defined more broadly.

Brammer et al. (2006) and Guatier and Pache (2015), reviewing the study of organizational philanthropy, distinguish three main approaches trying to explain the essence of this phenomenon (philanthropic motivations of the organizations described in the literature), namely:

1. A perspective in which philanthropy is perceived as a voluntary commitment of the company to contribute to the common good. The donor company does not expect direct compensation in this case (a condition of lack of reciprocity), which distinguishes philanthropy from sponsorship, and potential redress is uncertain and difficult to quantify; Philanthropy is the expression of the company's responsibility towards a broad group of stakeholders, a caring for the local communities in which it develops its business.

2. Philanthropy, understood as a long-term investment of the company, to support the urgent needs of various communities, provides the company with competitiveness and strengthens its business environment. Satisfying the urgent needs of the community, the company also serves to build mutual understanding, a sense of security, the creation of competent and educated workforce, and the development of infrastructure, thereby affecting the development of business-enabling conditions, and therefore essential for achieving competitive advantage. In this case, the company expects some non-financial, non-material redress in the form of, for example, improving its reputation, increasing prestige, feeling pride in its employees.

3. A marketing approach to philanthropy, where the gift is treated as a tool of commercial activity. The company should serve not only the consumer but also contribute to the welfare of the whole society. In this approach, philanthropy becomes a marketing strategy, that is what we know under the notion of social marketing, also called cause-related marketing, and its purpose is to build a positive attitude towards the company and to create a brand image.

Organizational philanthropy has a potential impact on all stakeholder groups, although not necessarily positive; regardless of the approach and in accordance with the general opinion in the literature, it is expected that philanthropy should ultimately benefit the company, although not directly (Gautier \& Pache, 2015). Organizational philanthropy is now widespread both in large international companies as well as in small and medium-sized enterprises (Gautier \& Pache, 2015). The trends presented in the literature on the scale of expenditure for philanthropic purposes, although limited mainly to the United States of America and Great Britain, are ambiguous. Some authors refer to a significant increase in corporate charity spending, except for the beginning of financial crisis in 2009 (Brammer et al., 2006; Gautir \& Pache, 2015), others point out their apparent decline (Porter \& Kramer, 2002), while others 
write about some stabilization in recent years (CECP, 2016). Philanthropy can be used by companies as a form of public relations to build or improve its image; it can be used as a supplement to advertising; as it is clear from Wang's and Qian's (2011) research, among the emerging Chinese companies listed on the stock market, the intensity of advertising has a negative effect on the probability of donations, suggesting rather their replacement than complementary character, at least in this case. Companies operating in the retail trade and business-to-customer industries (e.g. mass media, insurance, telecommunications) spend more on charity than the other (business-to-business), because their business is more noticed by consumers (Gautir \& Pache, 2015). The effectiveness of organizational philanthropy in the consumer choice process is ambiguous (Gautir \& Pache, 2015). Organizational philanthropy can strengthen a company's relationship with its habitual customers, thereby influencing their loyalty, but it can also contribute to the company's attractiveness (giving it a competitive advantage) as a place of employment for highly qualified staff looking for interesting work (Gautier \& Pache, 2015). Organizational philanthropy (accepted or recognized by the authorities of a country) can contribute to the creation of a generally favorable climate for business by a country's authorities; it can contribute to the support given by a country's authorities to the company, through various types of privileges, subsidies, and incentives, as well as economic barriers imposed on the other market participants; it can serve as means of gaining political support in countries where institutional conditions are insufficient. (Wang \& Qian, 2011; Gautier \& Pache, 2015). According to Forehand and Grier (2003, apud Gautier \& Pache, 2015), consumers don't like companies which try to hide the benefits of philanthropy.

Societal marketing, cause marketing or cause-related marketing (CRM) refers to the company's support for a specific social goal while enhancing its market position, image and reputation, through business cooperation with non-government organizations (ONGs) and consumer engagement. Social marketing is different from donations and philanthropy in that the donation can be tax deductible, and social marketing is based on social relationships that do not necessarily involve donations. Unlike the case of philanthropy, in social marketing, it is difficult to talk about a gift, because the amount of money transferred to a social goal is not donated by the company, but it is collected for a specific purpose as a result of linking it with the behavior of consumers choosing those and no other brands/goods in the purchase decisionmaking process (Gautier \& Pache, 2015). Social marketing seems to be more effective than philanthropy when it comes to increasing sales of goods (Gautier \& Pache, 2015). CRM can be a way to differentiate a company and a brand, since it has a positive impact on employee morale (increases the sense of pride in belonging to the company, contributes to increased commitment and productivity of employees), and can contribute to the healing of the company's damaged reputation (Cone, 2012; Gautier \& Pache, 2015). Organizational philanthropy and social marketing, as forms of social responsibility strategies, affect consumer trust and attitudes toward the product (Gautier \& Pache, 2015). The potential benefits of social marketing for a company include positive public relations, improved customer relationships, additional marketing opportunities (sales growth, customer loyalty, premium pricing or skim pricing, differentiation, competitive advantage) and greater revenue from sales. The benefits of social marketing result from the consumer's sense of being a philanthropist, when he does something as trivial as purchasing products from a particular brand or company engaged in that type of activity, or in other words, social marketing gives consumers the opportunity to participate in an altruistic initiative, which gives satisfaction to the people involved, helps the company achieve its objectives, and supports social initiatives (Guerreiro et al., 2016). The type of product promoted in a marketing campaign influences the effectiveness of social marketing (Gautier \& Pache, 2015). Strahilevitz and Myers (1998) have demonstrated that social marketing is more effective when it comes to superfluous luxury ("frivolous"/hedonic) products (e.g. chocolate truffles, perfumes, luxury boat cruises) than with practical (utilitarian) products 
(e.g. detergents, milk). If a consumer does not trust a company that is behind a social marketing campaign, it may be because he perceives it as a camouflaged and unwieldy form of gaining loyalty and attracting more consumers. Therefore, it is important that the marketing campaign is authentic and is linked to the brand image of the product involved in the social purpose. Not only the fit/relationship between the social goal and the brand affects the consumer's attitude toward the product involved in the marketing campaign, but also the consumer's familiarity with social problem: the greater the knowledge of a social problem, the less relevant is the impact of fit on the consumer's attitude towards the product, and the attitude toward the brand is increasing (Zdravkovic et al., 2010; apud Guerreiro et al., 2016). Consumers also tend to be skeptical about the amount of money actually donated to the social aim, about the money spent on a marketing campaign linked to this aim, and about the funds feeding directly the company (Guerreiro et al., 2016). It is therefore important that the company supporting the social purpose is transparent and disclose the number of funds used. The number of charity donations expressed as a percentage of the sales price or profit confounds consumers, so it is better to use it as an absolute measure, which in turn increases the effectiveness of social marketing (Guerreiro et al., 2016). The amount of donation to a social purpose associated with a given product strongly influences the choice made by the consumer, but also has its limits; if the size of donations is increasing along with the price of the product, the probability of purchase of the cause-related product decreases (Pracejus et al., 2003; Chang, 2008; Subrahmanyan, 2004; apud Guerreiro et al., 2016). Skepticism and distrust of consumers often involve poorly planned and organized philanthropic activities and marketing campaigns, perceived as corporate actions that utilize social goals to meet the company's own needs, such as increasing profits or increasing sales (Gautier \& Pache, 2015; Guerreiro et al., 2016); „,corporate reputation may be lost if financial interests (profit) overcome an honorable behavior of the company" (Guerreiro et al., 2016, p. 118). Certificates confirming compliance with environmental standards, social responsibility, sustainable development, occupational hygiene, etc., although they give the company/brand a competitive advantage, they can also cause consumer skepticism, because they do not prove that the company claims are sufficiently transparent to take advantage of consumer choice (Guerreiro et al., 2016). For small companies, a genuine commitment to the social goal increases customer's identification with their activity; in addition, small enterprises use social marketing to address the problems of local communities, giving them a competitive advantage, while large companies use social marketing campaigns to increase their reputation in controversial industries, and to mitigate the effects of future problems arising from their activity (Guerreiro et al., 2016). The success of a social marketing campaign in the case of one product can also bring brand image benefits to other products of the same brand, even if they are not linked to a social goal (Henderson \& Arora, 2010; apud Guerreiro et al., 2016).

Cone (2012), Gautier and Pache (2015) and Guerreiro et al. (2016) present the American Express credit card case (1983) as one of the first successful and ethically positive examples of social marketing whose purpose was to revitalize the Statue of Liberty in New York. At every card use, the owner/consumer made a small donation for the purpose, while the socially convincing goal, backed by a well-executed and extensive information campaign, generated over one and a half million US dollars of revenue for this purpose, and a double-digit increase in card usage (Cone, 2012; Guerreiro et al., 2016). However, Baghi, Rubaltelli, and Tedeschi (2009) criticize this action and point to a questionable ethical evaluation in this case (Statue of Liberty) as well as in another case of American Express initiative (Charge against hunger), for much of the money was spent on campaigns advertising both initiatives, rather than donated to social goals. Porter and Kramer (2002) describe exactly the same pattern of action in the case of Philip Morris, the tobacco tycoon, who collected 75 million US dollars for philanthropy in 1999, spending 100 million US dollars on advertising the entire venture. Another countereffective and ethically reprehensible example quoted by Baghi et al. (2009) was the case of an 
Italian telecommunications company that announced the launching of a one euro campaign for every text message (SMS) sent by mobile phone users in order to raise funds for charity, but in fact it began to charge additional fees for SMS, putting aside for charity only a small portion of the revenue from the entire campaign.

An example of successful and ethically positive social marketing, at least until now, may be the Delta Cafés campaign "Um Café por Timor" ("One Coffee for Timor") organized by the company under the initiative "Sustentabilidade nas Origens" ("Sustainable Development at the Origins"), to expand East Timor's local infrastructure, rebuild and equip schools, supply equipment for the processing of green coffee, practicing a fair price, etc. Within this campaign, every pack of Delta Timor coffee blend sold was sent to Timor 0.25 euros ( 1 euro per kilogram of coffee) (Delta Cafés, n.d.; Lindon et al., 2010).

\section{Communicating corporate social responsibility}

While some studies show that communicating social responsibility does not necessarily have a positive impact on the company, other studies present the company's CSR communication as being positively received and influencing increased trust in the company. (Morsing \& Schultz, 2006; Jahdi \& Acikdilli, 2009; Chaudhri, 2016). However, a variety of marketing available communications tools are generally not well perceived by consumers and a large part of the business (Jahdi \& Acikdilli, 2009; Garbarski, 2012). As Morsing and Schultz (2006) and Jahdi and Acikdilli (2009) note, companies that emphasize their achievements in social responsibility call more attention to themselves and are subject to greater criticism and social control than those that do not do it.

CSR is closely linked to ethics, and often the two fields overlap, but CSR and ethics are not the same thing, because CSR can be used to mask inappropriate ethical behavior or to try to wash away a blame (Drumwright \& Murphy, 2009; Lock et al., 2016). Likewise, stakeholder engagement, taken as a form of CSR, may not have ethical dimensions at all, or may even be a sign of lack of accountability (Greenwood, 2007).

CSR communication strategy affects not only company's reputation and trust of external stakeholders (or lack of them or loss), but also has an impact on its internal stakeholders, their willingness to identify with the workplace, their loyalty (or their missing/lost), etc.; communicating about company's CSR performance through external stakeholders is considered one of the most effective communication strategies, because it works even for those who usually do not believe in it. (Morsing, 2006; Morsing \& Schultz, 2006).

Morsing and Schultz (2006) write about three empirical strategies for communicating CSR activities:

1. Stakeholder information strategy, as one-way communication (monologue);

2. Response strategy to stakeholder issues, which is bi-directional, asymmetric communication;

3. The strategy of active involvement of key stakeholders, i.e. two-way, symmetric communication (dialogue), which serves to develop a common message about corporate actions within CSR.

In turn, Chaudhri (2016) describes three literature-dominant perspectives on CSR communication:

1. An instrumental approach in which communication is perceived as a strategic tool for optimizing the benefits of CSR. Company's initiatives under CSR are subordinated to the economic dimension of its business, aiming at risk avoidance and risk management (anticipating criticism), gaining competitive advantage, enhancing brand reputation, building a positive brand image and brand identity, winning consumer's loyalty and recruiting and motivation of employees; 
2. The relational approach, based on stakeholder theory, where commitment, openness and dialogue with the latter are concerned. This approach takes into account the influence and opinions of stakeholders in the decision-making process and builds a climate of mutual trust in order to achieve mutually satisfactory solutions. This approach corresponds to the third and last strategy in the Morsing and Schultz (2006) typology;

3. A constitutive approach in which the key role is played by the language and communication process understood as the creation of CSR meanings. According to this approach, organizations are the creations of communication, so CSR is constructed, legitimized and maintained in the communication process. This approach is also a key assumption in the Lock et al. (2016) study because the legitimacy of the organization "takes place through discourse during which CSR standards emerge from stakeholders' stated expectations regarding an organization's responsibility to society" (p. 87).

According to Jahdi and Acikdilli (2009), any means of marketing communication can serve as a way to convey corporate social responsibility message and may help to strengthen its brand image and brand value, but some are more effective (e.g. public relations, advertising, social marketing) than others. According to Chaudhri (2016), there is no one universal approach to CSR communication. In addition, the choice of means of communication depends on the target recipient (Jahdi \& Acikdilli, 2009).

According to surveys conducted in Denmark, Sweden and Norway, Scandinavian societies have mixed views on how companies should communicate (in the form of corporate advertising, corporate release, or minimal release) their CSR activities (Morsing \& Schultz, 2006).

Devin (2016) points out that companies often resort to half-truths, omitting essential information when communicating social responsibility, which contributes to undermining their credibility and honesty, and thus achieving counterproductive or counter-effective results. The half-truth, according to Devin (2016), is "the communication of technically correct, truthful information that has been, or has the potential to be, undermined by the omission of key information" (p. 226). As described by the author, the company may want to use its CSR reports for marketing purposes; the report gives the company the freedom to praise achievements, thereby influencing the market/stakeholder perception of its actions, but disclosing omissions of some relevant information can undermine the credibility of the information provided and compromise the reputation of the company, because what has not been said/written or has been unsaid may be equally important or even more important than what the content of the message is. According to Devin (2016), half-truth complements a set of inappropriate means of market communication that can undermine firms' credibility and destroy its reputation, joining the well-known from the literature such practices as organizational hypocrisy, greenwashing or lies.

According to Jahdi and Acikdilli (2009) and Lock et al. (2016), company's credibility the source of information about CSR activity, is one of the key requirements for the efficiency of the communication process, because companies operating in the so-called "socially irresponsible industries" or "sin" sectors (tobacco, alcohol, pornography, gambling, weapons, fuel, etc.), as well as companies with the stigma of bad reputations and/or legitimacy problems in the wake of the scandal, despite their efforts to convey an ethically acceptable and attractive image, are exposed to suspicion, skepticism, and hypocrisy accusations (Morsing \& Schultz, 2006; Jahdi \& Acikdilli, 2009).

The surveys conducted in Scandinavian countries (Denmark, Sweden and Norway) show that CSR communication should not be too intrusive or overemphasized to prevent the company from being suspected of wanting to conceal something bad and not become consequently counterproductive (Morsing \& Schultz, 2006). Chaudhri (2016), based on interviews conducted with CSR managers of large national and international companies in India, likewise emphasizes the need for subtle and balanced CSR communication. 
Tata and Prasad (2015) consider that, insofar as it is important to inform the audience about the CSR of an organization, it is also important that the CSR image perceived by the audience be compatible with the organizations' CSR identity, so that there is no incongruence between desired and current CSR images.

Morsing and Schultz (2006) draw attention to the research conducted by various authors on intercultural differences in attributing a different type of responsibility to companies and stakeholders' perceptions on permissible forms of CSR communication, for example, stronger in the USA and more hidden and silent in Europe. Since „what is considered a socially responsible behavior for one group may be considered an image management tool for another" (Tam, 2015, p. 119).

Another threat to the effectiveness of the message, according to Morsing and Schultz (2006), may be related to which CSR-linked activities will be selected by the company's top management and deemed appropriate to convey to the wider public and how this will be done, because what engages company executives, makes them proud and assumedly important, may not be in the interests of other stakeholders, and may even be perceived as inappropriate.

Inviting stakeholders to contribute to and influence the communication (report) of the CSR activities undertaken by the company contributes to the exchange of views, fears, suggestions, mutual understanding and increases the likelihood of positive identification with the company, because they feel they share responsibility for the implemented initiatives (Morsing \& Schultz, 2006). Supporting company's CSR initiatives and communications by external stakeholders make that the image of a company's activity is not completely cleared of problems and devoid of any criticism (Morsing \& Schultz, 2006). However, if there is no real partnership, invited stakeholders are treated instrumentally, then such initiatives are counterproductive, leading to a sense of loss of time, unnecessary costs, and loss of confidence and skepticism (Morsing \& Schultz, 2006).

According to an experimental research of Andreu, Casado-Diaz, and Mattila (2015), consumers' responses to CSR initiatives depend on the type of CSR stimulus (environment or employee-related issues), on the issue the message appeals (rational or emotional arguments) and the type of service provided (hedonic or utilitarian). Appealing to rational arguments is more effective in communicating CSR initiatives on the environment, while appealing to emotional arguments is more effective in communicating CSR initiatives related to employee issues; in both types of services (hedonic and utilitarian), there is a significant effect on consumers by assigning motives to engage the company in CSR; appealing to rational arguments of messages influences consumers' awareness of CSR issues and their emotional responses to utilitarian services (Andreu et al., 2015).

Tam's (2015) research shows that CSR events and information are more likely to be of interest to the press or to the media if they are more closely linked to the core business of the company and the greater their impact on society.

In recent times, CSR reporting is very popular among companies (Pichola, 2012; Moravcíkova et al., 2015; Chaudhri, 2016). CSR (sustainable development or social reports) reports can serve as a tool for managing an enterprise, measuring its (economic, social and environmental) responsibilities, and engaging stakeholders (dialogue) in CSR initiatives, as well as communicating the company's achievements outside (Pichola, 2012). These reports are voluntary and, in addition to the usual forms of communication with stakeholders, they also serve to win the goodwill of the public and strengthen the brand's reputation (Moravcíkova et $a l ., 2015)$. One of the more widespread is preparing a report based on general guidelines for sustainable development of Global Reporting Initiative (GRI) (https://www.globalreporting.org/Pages/default.aspx) (Pichola, 2012; Chaudhri, 2016). 


\section{Conclusion}

In this study, we discussed several issues related to the effectiveness of the selected tools of communication with the market and several ethical issues. With such a wide variety of topics and problems, many of which have been omitted, it seems impossible to summarize them without falling into banalities.

Companies in a competitive environment must communicate with the market, that is, with their stakeholders and intermediaries - "stakeholders without stakes" (cf. Frandsen \& Johansen). They have to do it to inform about their products/services, that is what they have to offer; they have to inform about the features and advantages of these products and services and the benefits they provide to customers/users; they have to do it in order to create, develop and strengthen the brand image; they have to do it to stop potential competitors from entering the industry; they have to do it to make the distribution not forget about selling company's products; they have to do it to be recognized by the competition and to make the market/stakeholders have no negative connotations related to the company/brand, etc. To achieve this goal, companies have many different means of communication at their disposal. The effectiveness of each of these measures and the related ethical issues, however, differ considerably. In addition, the development of new technologies and means of Internet communication provides new opportunities with a potential which is not fully recognized. This situation also creates new and unknown threats, both praxeological and ethical, which join those already known. These are often well-known problems and dangers, but in a new form, hidden under the "cover" of a new technology that can serve to mask their consequences, or actual goals, or justify someone's ignorance.

Companies are sometimes forced to inform what they do and how they do it, as required by national law or international norms, such as for products, services or investments likely to endanger the life or health of humans, animals or the environment, etc. Mergers, acquisitions, share capital increases, significant investments, the purchase of new technology, links to other corporations, and many other issues are also made public, as it may affect stock prices on the stock market. Companies are obliged to disclose information where it may promote corruption or impede free and fair competition, e.g. with certain types or amounts of purchases, in public contests, or in the case of domestic and foreign investments. Increasingly, industry-leading companies impose social responsibility or sustainability standards, which forces other organizations to undertake such activities and innovate in this field, in order not to be pushed out of the industry. Often in the supply chain, buyers require their suppliers to meet CSR or sustainability standards as a condition of purchase and further cooperation.

The failure of the company and its management to deal with the ethical dimension of communication with the market and stakeholders has a significant impact on the praxeological dimension of this communication, reducing its effectiveness or making it often counterproductive. However, there are no definite and general prescriptions for the final solution of these issues. As emphasized more than half a century ago by Finn (1959), the first and principal task of every company's executives is to identify and clarify the ethical limits of actions taken and the use of available resources in the process of communication, that is, what is allowed and what is unacceptable, influencing, through organizational communication, children and young people, adult consumers, government and its policies, schools, the media, public institutions, etc. The need for wide dissemination of information on unacceptable behavior is also mentioned by advertising industry professionals (Drumwright \& Murphy, 2009). Most executives of advertising and public relations agencies nowadays perceive their personal responsibility for ethical issues and for the promotion of transparency; however, there are still those who consider the amoral and self-interested approach to communication as more effective (Schauster \& Neill, 2017). 
To increase the transparency of the environmental performance of companies Delmas and Burbano (2011) advise reducing greenwashing, as well as facilitating access to knowledge about this phenomenon, etc., while Tata and Prasad (2015) consider that even the communication "about unfavorable actions, allows the organization to explain and justify its actions and increases transparency about social and environmental impact of the organization /.../; thus maintaining legitimacy" (p. 777). The need for transparency as a prerequisite for cause-related marketing is highlighted by Guerreiro et al. (2016). Leaders of today's leading advertising companies also raise transparency issues (versus concealment of identity, hidden advertising or product placement, public relations, etc.) for new non-traditional media (viral advertising/marketing, flogging vs. blogging, astroturfing/astroturf lobbying, product placement, etc.) as an important ethical issue (Drumwright \& Murphy, 2009). The same threats of dysfunctional communication (astroturfing, flogging, etc.) are also reported by other authors (e.g. Cádima, 2016; Lock et al., 2016). According to Lock et al. (2016) values such as credibility, trust, etc., form the basis for the quality of discourse in postmodern society.

\section{Acknowledgement}

The publication of this research has been financed by Instituto Politecnico de Setubal.

\section{References}

Andreu, L., Casado-Diaz, A. B., \& Mattila, A. S. (2015). Effects of message appeal and service type in CSR communication strategies. Journal of Business Research, 68, 1488-1495.

Baghi, I., Rubaltelli, E., \& Tedeschi, M. (2009). A strategy to communicate corporate social responsibility: cause related marketing and its dark side. Corporate Social Responsibility and Environmental Management, 16, 15-26.

Brammer, S., Millington, A., \& Pavelin, S. (2006). Is philanthropy strategic? An analysis of the management of charitable giving in large UK companies. Business Ethics: A European Review, 15(3), 234-245.

Buchholz, R. A., \& Rosenthal, S. B. (1998). Business ethics. Upper Saddle River: Prentice Hall.

Cádima, F. R. (2016). O (des)controlo da Internet: bad bots, astroturfing e flogging. Revista Brasileira de História da Mídia, 5(2), 205-216.

CECP (2016). Giving in numbers 2016 edition. CECP - Committee Encouraging Corporate Philanthropy, in association with The Conference Board. Retrieved March 28, 2017, from http://cecp.co/download-pdf-form/?pdflink=wpcontent/uploads/2016/11/GIN2016_Finalweb-1.pdf.

Chaudhri, V. (2016). Corporate social responsibility and the communication imperative: perspectives from CSR managers. International Journal of Business Communication, 53(4), 419-442.

Cone, C. L. (2012, August 15). Purpose: The Fifth 'P'. Marketing News, 30.

Davtyan, D., \& Cunningham, I. (2017). An investigation of brand placement effects on brand attitudes and purchase intentions: Brand placement versus TV commercials. Journal of Business Research, 70, 160-167.

Delmas, M. A., \& Burbano, V. C. (2011). The drivers of greenwashing. California Management Review, 54(1), 64-87.

Delta Cafés (n.d.). Retrieved March 6, 2015, from http://www.delta-cafes.pt/.

Devin, B. (2016). Half-truths and dirty secrets: omissions in CSR communication. Public Relations Review, 42, 226-228. 
Drumwright, M. E., \& Murphy, P. E. (2009). The current state of advertising ethics. Journal of Advertising, 38(1), 83-107.

Dudley, P. (1995). Editor's Introduction. In P. Dudley (ed.), Kotarbiński's Praxiology (pp. xivxxix). Hull (UK): Centre for Systems Studies Press.

Edelman, D. J. (2006). The golden age of public relations. Public Relations Quarterly, 51(1), 20-21.

Eagle, L., \& Dahl, S. (2015). Product placement in old and new media: examining the evidence for concern. Journal of Business Ethics, (In Press).

Finn, D. (1959). Struggle for Ethics in Public Relations. Harvard Business Review, 37(1), 49-53.

Frandsen, F., \& Johansen, W. (2015). Organizations, stakeholders, and intermediaries: towards a general theory. International Journal of Strategic Communication, 9, 253-271.

Freeman, R. E. (2002). The possibility of stakeholder capitalism. In: L. Zsolnai \& W. W. Gasparski (eds.), Ethics and the future of capitalism (pp. 111-116). New Brunswick: Transaction Pub.

Freire, A. (1998). Estratégia. Sucesso em Portugal. Lisboa: Verbo.

Gasparski, W. (1993). Tadeusz Kotarbiński's Philosophy as a Philosophy of Practicality. In: T. Airaksinesn \& W. W. Gasparski (eds.), Practical Philosophy and Action Theory (pp. 93-101). New Brunswick: Transaction Pub.

Garbarski, L. (2012). Etyczne aspekty działań marketingowych. In: W. Gasparski (ed.), Biznes, etyka, odpowiedzialność (pp. 64-78). Warszawa: Wydawnictwa Profesjonalne PWN.

Gautier, A., \& Pache, A.-C. (2015). Research on corporate philanthropy: a review and assessment. Journal of Business Ethics, 126, 343-369.

Greenwood, M. (2007). Stakeholder engagement: beyond the myth of corporate responsibility. Journal of Business Ethics, 74, 315-327.

Grzegorczyk, A. (1989). Mała propedeutyka filozofii naukowej. Warszawa: Pax.

Guerreiro, J., Rita, P., \& Trigueiros, D. (2016). A text mining-based review of cause-related marketing literature. Journal of Business Ethics, 139, 111-128.

Hallahan, K. (1994). Public relations and circumvention of the press. Public Relations Quarterly, 39(2), 17-19.

Hazaparu, M.-A. (2014). Setting the agenda in advertising: understanding ethical dilemmas from a communicative perspective. Comunicação e Sociedade, 25, 328-342.

Jahdi, K. S., \& Acikdilli, G. (2009). Marketing communications and corporate social responsibility (CSR): marriage of convenience or shotgun wedding? Journal of Business Ethics, 88, 103-113.

Karnaukhova, N. A., \& Polyanskaya, E. V. (2016). Communication and reputation as essentials for the positioning of an organization. AI \& Society, 31, 371-379.

European Commission (2001). Green paper. Promoting a European framework for corporate social responsibility. Brussels. Retrieved May 11, 2011, from http://eurlex.europa.eu/LexUriServ/LexUriServ.do?uri=COM:2001:0366:FIN:en:PDF.

Kotler, P., Armstrong, G., Sanders, J., \& Wong, V. (1996). Principles of Marketing. The European Edition. London - Munich: Prentice Hall.

Kotler, P. (1967/94). Marketing Management. Analysis, Planning, Implementation, and Control. Englewood Cliffs (NJ): Prentice Hall International, Inc.

Kowalczyk, C. M., \& Royne, M. B. (2012). Are products more real on reality shows? An exploratory study of product placement in reality television programming. Journal of Current Issues \& Research in Advertising, 33(2), 248-266.

Kuraszko, I. (2012). Etyka w komunikowaniu społecznym przedsiębiorstwa. In: W. Gasparski (ed.), Biznes, etyka, odpowiedzialność (pp. 154-164). Warszawa: Wydawnictwa Profesjonalne PWN. 
Lai, C. J. (2016). The effect of individual market orientation on sales performance: an integrated framework for assessing the role of formal and informal communications. Journal of Marketing Theory and Practice, 24(3), 328-343.

Lindon, D., Lendrevie, J., Lévy, J., Dionísio, P., \& Rodrigues, J. V. (1992/2010). Mercator XXI. Teoria e prática do marketing. Alfragide: Publicações Dom Quixote.

Lock, I., Seele, P., \& Heath, R. L. (2016). Where grass has no roots: the concept of 'shared strategic communication' as an answer to unethical astroturf lobbying. International Journal of Strategic Communication, 10(2), 87-100.

Mitchell, T. R. (1982). People in organizations: an introduction to organizational behavior. Tokyo: McGraw-Hill.

Moravcíkova, K., Stefanikova, L., \& Rypakova, M. (2015). CSR reporting as an important tool of CSR communication. Procedia Economics and Finance, 26, 332-338.

Morsing, M. (2006). Corporate social responsibility as strategic auto-communication: on the role of external stakeholders for member identification. Business Ethics: A European Review, 15(2), 171-182.

Morsing, M., \& Schultz, M. (2006). Corporate social responsibility communication: stakeholder information, response and involvement strategies. Business Ethics: A European Review, 15(4), 323-338.

Ossowska, M. (1970/85). Normy moralne. Próba systematyzacji. Warszawa: PWN.

Pichola, I. (2012). Raportowanie i ocena społecznej odpowiedzialności. In: W. Gasparski (ed.), Biznes, etyka, odpowiedzialność. Warszawa: Wydawnictwa Profesjonalne PWN.

Porter, M. E., \& Kramer, M. R. (2002). The competitive advantage of corporate philanthropy. Harvard Business Review, 80(12), 57-68.

Schauster, E., \& Neill, M. (2017). Have the ethics changed? An examination of ethics in advertising and public relations agencies. Journal of Media Ethics, 32(1), 45-60.

Smarandescu, L., \& Shimp, T. A. (2015). Drink coca-cola, eat popcorn, and choose powerade: testing the limits of subliminal persuasion. Marketing Letters, 26, 715-726.

Strahilevitz, M., \& Myers, J. G. (1998). Donations to charity as purchase incentives: how well they work may depend on what you are trying to sell. Journal of Consumer Research, $24,434-446$.

Tam, L. (2015). News about corporate social responsibility (CSR): the interplay of intermedia agenda setting influences between corporate news releases and press coverage. Asian Journal of Business Ethics, 4(2), 117-130.

Tata, J., \& Prasad, S. (2015). CSR communication: an impression management perspective. Journal of Business Ethics, 132, 765-778.

Uribe, R., \& Fuentes-García, A. (2015). The effects of TV unhealthy food brand placement on children. Its separate and joint effect with advertising. Appetite, 91, 165-172.

Wang, H., \& Qian, C. (2011). Corporate philanthropy and corporate financial performance: the roles of stakeholder response and political access. Academy of Management Journal, 54(6), 1159-1181. 